\title{
Commentary: My precious
}

\author{
Peter H. U. Lee, MD, PhD, MPH, and Nahush A. Mokadam, MD, FACS, FACC
}

From the Division of Cardiac Surgery, The Ohio State University Wexner Medical Center, Columbus, Ohio. Disclosures: Mokadam is a consultant and an investigator for Abbott, Medtronic, and SynCardia. Lee has nothing to disclose with regard to commercial support.

Received for publication April 30, 2019; accepted for publication April 30, 2019; available ahead of print June 18, 2019.

Address for reprints: Nahush A. Mokadam, MD, FACS, FACC, Division of Cardiac Surgery, N-825 Doan Hall, 410 W. 10th Ave, Columbus, OH 43210 (E-mail: Nahush.Mokadam@osumc.edu).

J Thorac Cardiovasc Surg 2020;159:1354-5

$0022-5223 / \$ 36.00$

Copyright $\Subset 2019$ by The American Association for Thoracic Surgery

https://doi.org/10.1016/j.jtcvs.2019.04.104

With the continued growth and aging of the US population, the expansion and durability of left ventricular assist devices implanted as a bridge to transplantation, and improved medical management of patients with heart failure, the pool of patients needing and being listed for heart transplantation continues to increase. ${ }^{1}$ Between 2006 and 2017, the number of candidates actively awaiting a heart transplant dramatically increased $119 \% .{ }^{1}$ For a variety of reasons, including public reporting, tight scrutiny from transplant committees, and our deep commitment to our patients, attempts at donor pool expansion often have been met with skepticism. Nonetheless, starting with a handful of progressive centers and then extending into the mainstream are a needed expansion of what is considered an "acceptable" donor heart. In recent years, donors who are older, who have hepatitis $\mathrm{C}$ or human immunodeficiency virus, who are considered high risk by the Centers for Disease Control, and who have had a cardiac arrest with cardiopulmonary resuscitation are being more widely considered. ${ }^{2-4}$ For the first time in many decades, we have seen a small but real increase in heart transplant volume. $^{1}$

In this issue of the Journal, Jawitz and colleagues, ${ }^{5}$ using the United Network for Organ Sharing database, provide a powerful argument that waiting longer after brain death in selected donors does not negatively affect outcomes, which was a widely held misconception. ${ }^{5}$ The practical implication is that there may be an opportunity to accept more donor hearts if we allow hearts with post-cardiac arrest or post-brain death catecholamine surge dysfunction to recover. In 2010 , only $32 \%$ of the donor hearts were accepted for transplantation in the United States. ${ }^{6}$ Surely a fraction of those that were declined, if given enough time, could have recovered sufficiently for transplantation. We may be missing an opportunity to maximize our limited donor organ pool.

Each spring during Donate Life Month at The Ohio State University Wexner Medical Center, we plant an 8-armed pinwheel ( 1 arm for all 8 potential transplanted organs) in honor of every organ donor on our front lawn (Figure 1). This year, we planted approximately 10,000 of these

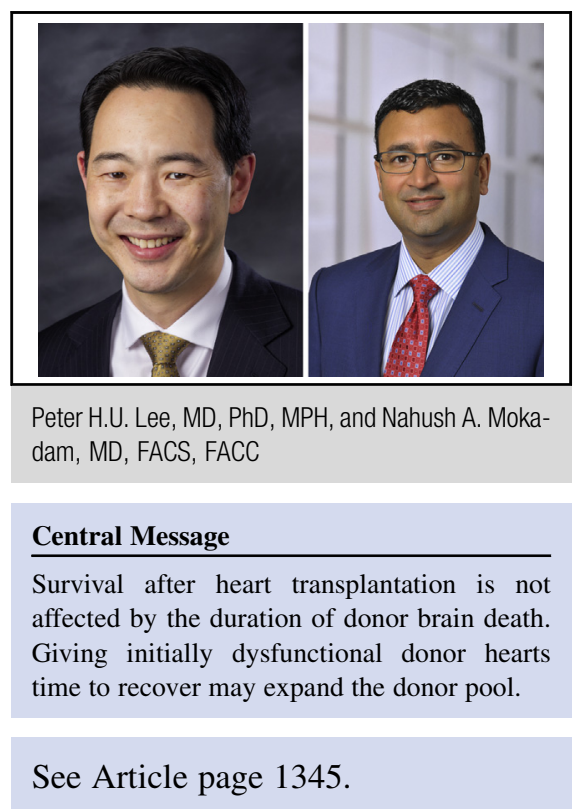

pinwheels. We easily have space available for another 10,000 and have a mindset to achieve this in a shorter period of time. Our challenge now is to mitigate all of the nonclinical factors that affect the timing of the donor operating room. Whether they are factors related to the donor hospital, the many recipient hospitals, the issues with travel, or the donor family preference, we, as a transplant community, should mandate to maximize the use of ALL available organs. This article ${ }^{5}$ provides one additional justification for giving the donor, when medically appropriate, more time to recover heart function, despite increasing the time from brain death to organ procurement. If we are to truly

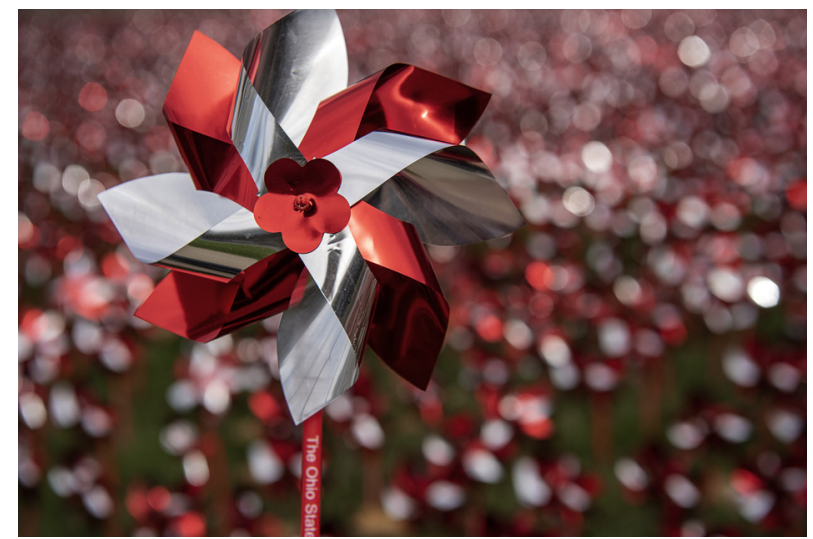

FIGURE 1. Eight-armed pinwheels, representing all 8 transplanted solid organs, are planted each spring at The Ohio State University Wexner Medical Center honoring our 10,000 organ donors. 
maximize the benefits of transplantation for the largest number of patients, we need to push back on the nonclinically driven rhetoric that is prematurely bringing donors to the operating room. Let us not let the Gift of Life go to waste. It is too precious.

\section{References}

1. Colvin M, Smith JM, Hadley N, Skeans MA, Uccellini K, Lehman R, et al. OPTN/ SRTR 2017 Annual Data Report: heart. Am J Transplant. 2019;19(Suppl 2): 323-403.

2. Quader MA, Wolfe LG, Kasirajan V. Heart transplantation outcomes from cardiac arrest-resuscitated donors. J Heart Lung Transplant. 2013;32:1090-5.
3. Gaffey AC, Cucchiara AJ, Goldberg LR, Blumberg EA, Acker MA, Atluri P. Transplantation of center for disease control "high-risk" donor hearts does not adversely impact long-term outcomes in adults. J Card Fail. 2016;22: 376-82.

4. Blanche C, Kamlot A, Blanche DA, Kearney B, Magliato KE, Czer LS, et al. Heart transplantation with donors fifty years of age and older. J Thorac Cardiovasc Surg. 2002; 123:810-5.

5. Jawitz OK, Raman V, Barac Y, Anand J, Patel CB, Mentz RJ, et al. Influence of donor brain death duration on outcomes following heart transplantation: a United Network for Organ Sharing Registry analysis. J Thorac Cardiovasc Surg. 2020; 159:1345-53.e2.

6. Khush KK, Zaroff JG, Nguyen J, Menza R, Goldstein BA. National decline in donor heart utilization with regional variability: 1995-2010. Am J Transplant. 2015; 15:642-9. 